\title{
The Relationship between Performance Appraisal Satisfaction and Employee Outcomes: With Special Reference of Bank of Ceylon Head Office
}

\author{
Weerakkody W.A.S. ${ }^{1}$, Mahalekamge W.G.S. ${ }^{2}$ \\ ${ }^{1}$ Department of Human Resource Management, \\ University of Kelaniya, Kelaniya, Sri Lanka. \\ was@kln.ac.lk \\ ${ }^{2}$ Department of Human Resource Management, \\ University of Kelaniya, Kelaniya, Sri Lanka. \\ geethanimahalekamge@yahoo.com
}

\section{Abstract}

The HR practice of Performance appraisal (PA) positively influences employee behavior and performance. The purpose of the present study is to examine the relationship between performance appraisal satisfaction and employee outcomes, in the form of employees' motivation, work performance and employees' commitment. Base on that purpose, BOC Head office was selected to conduct this research. The research framework consists of independent variables, and a dependent variable. The independent variable of the study is PA satisfaction and dependent variable is employee outcomes. Dependent variable divided in to three sub variables; employees' motivation, 
work performance and employees' commitment. Three hypotheses were formulated to be tested under this study. To collect data a structured questionnaire was used and distributed among the 110 sample by using the simple random sampling method. The data was analyzed through correlations of variables and regression in order to answer for the Hypothesis of the study. The results indicate that there is a weak but positive relationship between performance appraisal satisfaction and employee outcomes. And also there is an impact of performance appraisal satisfaction on employee outcomes. According to the analysis, $10 \%$ impact of Performance Appraisal satisfaction on employees' motivation, $14 \%$ impact of Performance Appraisal satisfaction on work performance and 5\% impact of Performance Appraisal satisfaction on employees' commitment. Thus, in order to obtain positive outcomes, organization should provide a performance appraisal platform where employees must create satisfaction with performance appraisal.

Keywords: Employee commitment, Employee motivation, Employee outcomes, Performance appraisal, Work performance

\section{Introduction}

Over the years, Human Resource Management has grown from being a simple series in the business world to be one of the most important business disciplines which has a strategic significant. Rather than 
people was being considered just as another machine, humans are now considered as the very important resource in the business. Thus managing the employee performance has become a vital element in the human resource management context. The performance appraisal is an important aspect of the human resource management system which helps the management to measure and appraise the employee performance in order to achieve organizational objectives.

Therefore banks also use this system to increase competency level of the employees and their work performance, commitment, motivation etc... to achieve the competitive advantages.

BOC is the well recognize public bank in Sri Lanka. They use MBO as their performance appraisal method. Earlier they use term of performance and potential appraisal system (PPA). It is very lengthy report and not having self appraisal. And also it has quarterly review. It weight under goals-50\%, behavior-30\% and job knowledge-20\% and not have proper marking scheme. So it had some biasness and not fair one and it did not work properly. So expected results were not gain from old PPA system. In some way not having proper PA system affected other HR functions such as promotion and training and development.

So managers decided to introduce new performance appraisal system (PAS) by modifying earlier system with effect from year 2013. 
Initially the PAS was applicable for clerical staff and junior executive officers and above grades. The existing PAS have self appraisal and weight under KPA (SMART Goals) $-70 \%$ and competencies $-30 \%$. It is very simple with having only two pages. And also have two periodical reviews of midyear and year end review. The targets are establishing at beginning of the year and arrange training program in each year for each individual. So it causes to change the perception of PAS system and satisfaction of PAS system influence to employees' outcomes. Through observe the behavior of the employees' researcher identify that employees are performed well to achieve their target and they are committed to their work and the organization and increase the motivation and morale.

\section{Research Problem}

Considering the situation in BOC, it is important to find out the relationships between satisfaction of performance appraisal (PA) system and employee outcomes in the form of work performance, employee commitment and employee motivation with special reference of Bank of Ceylon Head office. And also there has been very minimal or less empirical research to investigate the relationship between PA satisfaction and employee outcomes in the form of employee motivation, work performance and employee commitment, especially in exploring the perception of employee towards PA and whether this perception will have a heavy impact and influence on the 
employee outcome, in the banking sector. Therefore the overall research problem is, what is the relationship between Performance Appraisal satisfaction and employees outcomes in the form of employee motivation, work performance and employee commitment?

\section{Research Objectives}

1. To determine the relationship between Performance Appraisal satisfaction and employee motivation.

2. To determine the relationship between Performance Appraisal satisfaction and employee work performance.

3. To determine the relationship between Performance Appraisal satisfaction and employee commitment.

4. To find the outcomes of Performance Appraisal satisfaction.

5. Propose the suggestions to improve PA system and to satisfy employees regarding PA system.

\section{Literature Review}

\section{Performance Appraisal System}

Performance appraisal has a brief history starting from earth 20th century where the need of performance appraisal was felt and some measures developed as in Jabeen (2011) noted that Performance appraisal is the process of identifying, observing, measuring and developing human resources in organizations. As in Salleh et al (2013) 
according to Scott (2009), define that performance appraisal is the measurement of work and its results by using the scale and index that we can measure the desired quantity and quality with precision and free of personal judgments and vague criteria of evaluation.

Furthermore, PA served as a tool for managing the effectiveness and efficiency of employees and it is a vital component of a broader set of human resource practices. It is the mechanism for evaluating the extent to which each employee's day to day performance is linked to the goals established by the organization (Coutts and Schneider 2004, as in Vigneswaran, 2005).

\section{Performance Appraisal Satisfaction and Employee Motivation}

Motivation can be show as internal and external factors that stimulate desire and energy in people to be continually interested in and committed to a job, role, or subject, and to exert continual effort in attaining a goal. Motivation results from the inter actions among conscious and unconscious factors such as the (1) intensity of desire or need, (2) incentive or reward value of the goal and (3) expectations of the individual (Business Dictionary 2011, as in Luomanpaa, 2012)

According to Armstrong (2000 ss in Selvarajan et al 2011) performance appraisals provide a important point for the employee to consider motivational and development issues by providing positive 
feedback, recognition and opportunities for growth, a basis for developing capabilities for the current role and future roles the employee might have to perform.

When individuals see how good they are performing and understand what performance goals they can achieve in future they tend to be motivated to improve their performance (Hannay, 2010 as in Selvarajan et al 2011).

\section{Performance Appraisal Satisfaction and Work Performance}

According to Honiball (2008 as in Frese \& Sonnentag 2001), Work performance is the action or behavior that is relevant to achieving an organization's goals, whereas performance management is the process of linking organizational goals to departmental, team and individual goals. And also Performance can refer to the performance of an organization, department, primary process or a person .Work performance is described as the quality and quantity of human output that is necessary to meet work goals and the standards that are required to do a specific job. (Ivancevich \& Matteson, 1996 as in Vigneshwaran, 2005)

As in Vignashvaran (2005), Gerhart (2004) define that more specifically, these HR practices increase organizational effectiveness by creating conditions where employees become highly involved in 
the organization and work hard to accomplish organizational goals. HR practices are expected to influence both, organization's and employee's performance via the workforce's ability (e.g. using selective hiring, training), motivation (e.g. pay for performance by using PA), and opportunity to contribute (e.g. using teams and suggestion systems).

\section{Performance Appraisal Satisfaction and Employee Commitment}

Employee commitment is an attitude reflecting employees' loyalty to their organization and is an ongoing process through which organizational participants express their concern for the organization and its continued success and well being (Lutahn, 1998). Employee commitment is has three major components: (1) a strong belief in and acceptance of the organization's goals, (2) a willingness to exert considerable effort on behalf of the organization, and (3) a definite desire to maintain organizational membership) ( Porter 1974) (As in Angle \& Perry 1981). These three constructs are proven to carry high validity in the measurement of employee commitment. Employee commitment is the identification of organizational members with organizational goals and values and willingness of organizational members to go an extra mile in order to assist their organization to achieve goals (Hsu-Chung Chieh, 2006 as in Wang, Lee and Chih Ho 2012) 
There are different definitions of employee commitment given varying research methods, subjects and goals. There are three type of commitment construct. Those are retention commitment, value commitment and effort commitment as the main constructs (Shu-Hua Ting, 2000 as cited in Wang, Lee and Chih Ho 2012)

Performance appraisal is viewed as an important mechanism for changing employees' attitude and behaviors such as commitment (Morrow, 2011 as in Vigneswaran, 2005). As in Jamil (2012) according to Lee and Bruvold, Kuvaas (2006) noted that employees will probably show higher commitment to the organization if they perceive that PA activities reflects employee's development as well as Roberts and Reed (1996) noted that employee participation and perceived clarity of goals within the PA process.

\section{Conceptual Framework}

In this study the Performance Appraisal satisfaction is the independent variable and employee outcome is dependent variable. Employee motivation, work performance and employee commitment are sub variables under employee outcome 


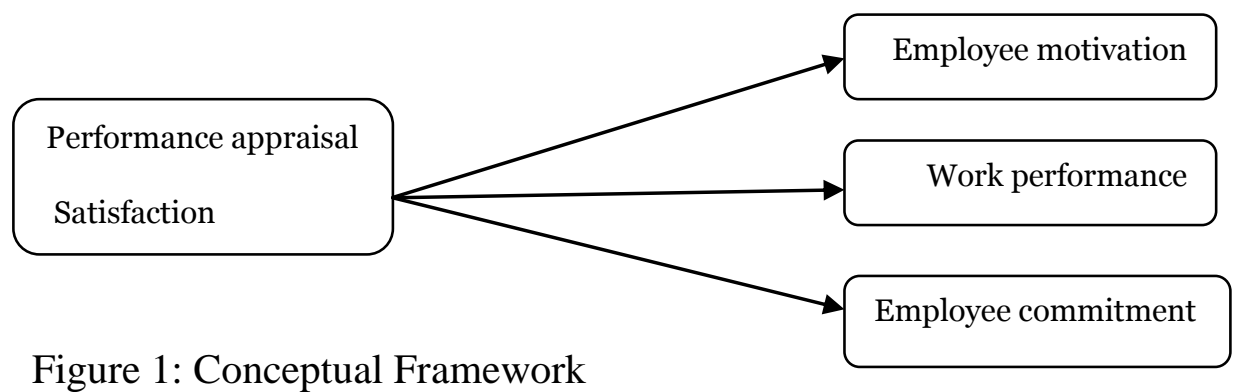

\section{Hypothesis of Study}

H1: There is significant relationship between Performance Appraisal satisfaction and employee motivation

H2: There is significant relationship between Performance Appraisal satisfaction and employee work Performance

H3: There is significant relationship between Performance Appraisal satisfaction and employee Commitment

\section{Methodology}

7.1 Sampling Method: Simple random sampling method is the technique used by the researchers as sampling method to provide equal opportunities to the population being in the sample. Here the sample consists 110 employees in BOC Head office from 900 employees (population). Here the sample is consisting with five departments of 
HR Operations, Superannuation, Staff services, Training and Welfare which consists with three levels of employees such as, Clerical employees (staff assistant, secretarial and typist), Executive officers and Chief Mangers/Managers/Assistant managers.

7.2 Method of Data collection: The questionnaire consists 36 close ended questions. Researchers used standard questionnaires. Satisfaction of PA system is measured by the questionnaire developed by Rajendran Vigneshwaran, 2005. Employee motivation was measured by questionnaire on employee motivation published by Samurdh Jahagirdar (2012). Work performance of workers measured by using the questionnaire developed by Rajendran Vigneshwaran (2005). And also Employee commitment was measured by the 10 -item Employee commitment Questionnaire (OCQ) (Porter et al., 1974) as cited in Luthan (1998). Reliability of questionnaire is 0.7 (Cronbatche's Alpha Value).Therefore questionnaire is supporting to measure that particular variable.

\subsection{Data analysis}

Quantitative method was used to analyze the data. The data analyzed in this study based on the questionnaires. Under the quantitative method, the Likert Scale was included to measure the relationship between PA satisfaction and employee outcome. 5 point Likert- scales were used to score the responses from strongly agree to Strongly 
disagree. Correlation analysis and simple regression analysis was used to find the impact and the relationship between the satisfaction of performance appraisal and employee outcome in the form of work performance, employee commitment and employee motivation.

\section{Frequency Distribution Analysis for Demographic Factors (Majority of the results)}

Table 1: Frequency Distribution Analysis for Demographic Factors

\begin{tabular}{llll}
\hline Factor & Majority & Frequency & Percentage \\
\hline Gender & Female & 45 & $60.0 \%$ \\
Age & $25-29$ & 23 & $30.7 \%$ \\
Education & G.C.E.A/L & 31 & $41.3 \%$ \\
Experience & More than 10 Years & 24 & $32.0 \%$ \\
Job position & Executive Officers & 35 & $46.7 \%$ \\
Department & HR Operation & 30 & $40.0 \%$ \\
\hline
\end{tabular}

\section{Statistic of the distribution of independent and dependent variables}

The Descriptive statistic analysis was made separately for the Independent variable of performance appraisal satisfaction and dependent variables of employee motivation, work performance and employee commitment. In this analysis, mean, median, mode, Std. deviation, skeweness and kurtosis used to explain the characteristics of the data. 
Table 2- Statistic of the distribution of Performance Appraisal satisfaction

\begin{tabular}{|l|r|}
\hline Mean & 4.413 \\
\hline Median & 4.000 \\
\hline Mode & 4.000 \\
\hline Std Seviation & 0.496 \\
\hline
\end{tabular}

Source: Survey data

The frequency distribution of Performance Appraisal satisfaction is presented in the table. As indicated by the table the mean value of the distribution is 4.4133. Therefore the Performance Appraisal satisfaction of employees is "High"

Table 3- Statistic of distribution of employee motivation of the Sample

\begin{tabular}{|l|r|}
\hline Mean & 4.613 \\
\hline Median & 4.000 \\
\hline Mode & 4.000 \\
\hline Std. Deviation & 0.490 \\
\hline
\end{tabular}

Source: Survey data

According to the table 4 the mean value of employee motivation is 4.6133 and Std. Deviation is 0.490. Therefore the employee motivation is "High". 
Table 4- Statistic of distribution of work performance of the Sample

\begin{tabular}{|l|l|}
\hline Mean & 4.547 \\
\hline Median & 5.000 \\
\hline Mode & 5.000 \\
\hline Std. Deviation & 0.501 \\
\hline
\end{tabular}

\section{Source: Survey data}

As well as according to the table 5 the mean value of work performance is 4.547 and Std. Deviation is 0.501. Therefore work performance was perceived to be the Highest in the BOC head office. And also according to table 6 mean value of employee commitment is 4.6 and Std. Deviation is 0.493 . Therefore employees' commitment is "High" in this organization.

Table 5- Statistic of distribution of employee commitment of the Sample

\begin{tabular}{|l|l|}
\hline Mean & 4.600 \\
\hline Median & 5.000 \\
\hline Mode & 5.000 \\
\hline Std. Deviation & 0.493 \\
\hline
\end{tabular}

Source: Survey data 


\section{Regression Analysis}

Simple Regression analysis was done for this study. This analysis was done for each variable separately. The table shows the results. Simple linear regression analysis, the adjusted $\mathrm{R}$ square determines that to what extent employee outcome such as employee motivation, work performance and employee commitment are explained by Performance Appraisal satisfaction.

\section{Simple Regression Analysis of Impact of Performance Appraisal satisfaction on Employee motivation}

Table 6: Simple Regression Analysis of Performance Appraisal satisfaction on Employee motivation

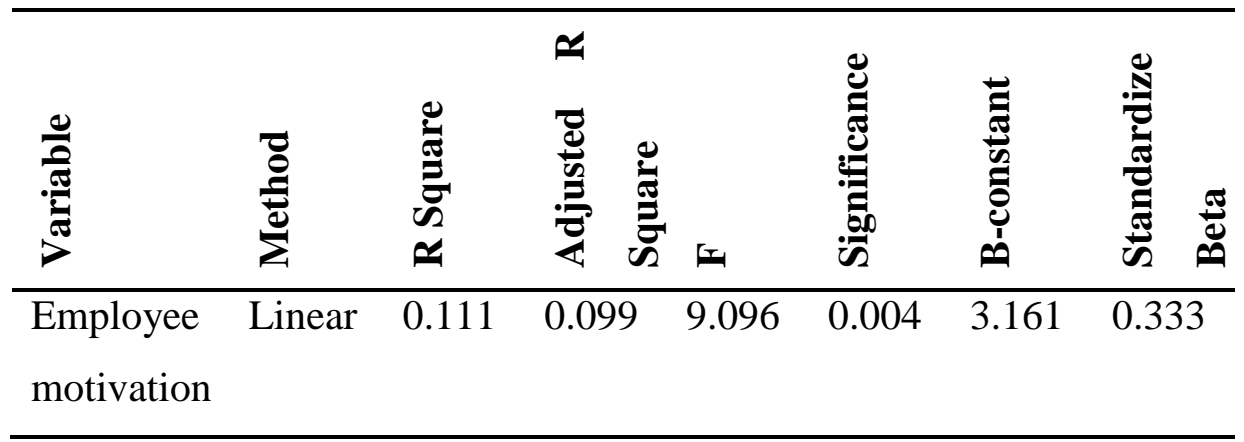

Source: Survey data

According to table 7 regression equation is, Employee motivation= $3.161+0.333$ Performance Appraisal satisfaction. As indicated by table 7 adjusted $\mathrm{R}$ square is $10 \%$ of the variance of employee motivation is explained by Performance Appraisal satisfaction. It 
Kelaniya Journal of Human Resource Management

Volume 8 Number 2 July 2013

has $10 \%$ impact of Performance Appraisal satisfaction on employee motivation.

Simple Regression Analysis of Impact of Performance Appraisal satisfaction on work performance

Table 7: Simple Regression Analysis of Performance Appraisal satisfaction on work performance

\begin{tabular}{|c|c|c|c|c|c|c|c|}
\hline$\frac{\frac{0}{0}}{\frac{\sigma}{\pi}}$ & 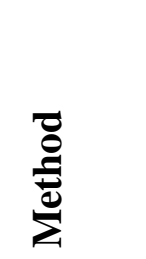 & 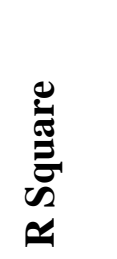 & 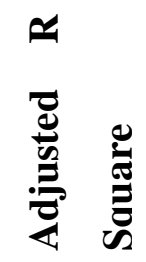 & I & 泀 & 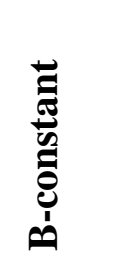 & 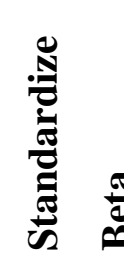 \\
\hline $\begin{array}{l}\text { work } \\
\text { performance }\end{array}$ & Linear & 0.147 & 0.135 & 12.598 & 0.001 & 2.835 & 0.384 \\
\hline
\end{tabular}

Source: Survey data

According to table 8 regression equation is, Work Performance= $2.835+0.384$ Performance Appraisal satisfaction. As indicated by table 8 adjusted $\mathrm{R}$ square is $14 \%$ of the variance of work performance is explained by Performance Appraisal satisfaction. It has $14 \%$ impact of Performance Appraisal satisfaction on work performance. 


\section{Simple Regression Analysis of Impact of Performance Appraisal satisfaction on employee commitment}

Table 8: Simple Regression Analysis of Performance Appraisal satisfaction on employee commitment

\begin{tabular}{|c|c|c|c|c|c|c|c|}
\hline 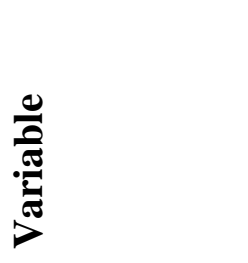 & $\frac{\vec{D}}{\stackrel{D}{e}}$ & 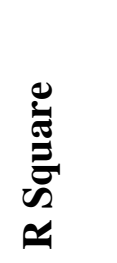 & 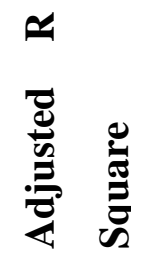 & 5 & 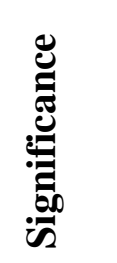 & 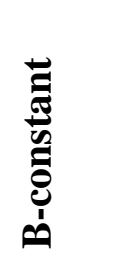 & 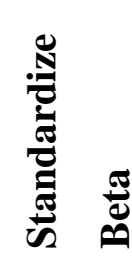 \\
\hline $\begin{array}{l}\text { work } \\
\text { performance }\end{array}$ & Linear & 0.059 & 0.046 & 4.589 & 0.036 & 3.532 & 0.243 \\
\hline
\end{tabular}

Source: Survey data

According to table 9 regression equation is, Employee commitment = $3.532+0.243$ Performance Appraisal satisfaction. As indicated by table 9 adjusted $\mathrm{R}$ square is 5\% of the variance of employee commitment is explained by Performance Appraisal satisfaction. It has 5\% impact of Performance Appraisal satisfaction on employee commitment.

\section{Correlation Analysis}

Using the Pearson Product Movement Correlation with two-tailed test of significance, the correlation analysis was made to investigate the relationships of performance appraisal satisfaction and employee outcome in the form of employee motivation, work performance and employee commitment. 
Kelaniya Journal of Human Resource Management

Volume 8 Number 2 July 2013

Table9: Correlation among the variables

\begin{tabular}{lrrrr}
\hline & PAS & $\begin{array}{r}\text { Employee } \\
\text { Motivation }\end{array}$ & $\begin{array}{r}\text { Work } \\
\text { performance }\end{array}$ & $\begin{array}{r}\text { Employee } \\
\text { Commitment }\end{array}$ \\
\hline PAS & 1 & $.333^{* *}$ & $.384^{* *}$ & $.243^{*}$ \\
Employee Motivation & $.333^{* *}$ & 1 & $.267^{*}$ & $.358^{* *}$ \\
Work performance & $.384^{* *}$ & $.267^{*}$ & 1 & $.569^{* *}$ \\
Employee Commitment & $.243^{*}$ & $.358^{* *}$ & $.569^{* *}$ & 1 \\
\hline
\end{tabular}

Notes:

PAS $=$ Performance Appraisal Satisfaction

** Correlation is significant at the 0.01 level (2-tailed)

* Correlation is significant at the 0.05 level (2-tailed)

According to the table it is noted that performance appraisal satisfaction is positively yet weakly correlated $(\mathrm{r}=.333, \mathrm{p}<0.01)$ with employees' work performance. As well as there is positive but weak relationship between performance appraisal satisfaction and work performance $(\mathrm{r}=.384, \mathrm{p}<0.01)$. And also according to the above table it is noted that performance appraisal satisfaction is positively yet weak correlated $(\mathrm{r}=.243, \mathrm{p}<0.05)$ with employees' commitment.

\section{Findings and Discussion}

According to the survey data it had $10 \%$ impact of Performance Appraisal satisfaction on employees' motivation, 14\% impact of performance appraisal satisfaction on work performance and 5\% impact of performance appraisal satisfaction on employees' 
commitment. Therefore PA satisfaction highly influence to increase work performance than employees' motivation and employees' commitment.

This study revealed that there exist a relatively weak relationship between performance appraisal satisfaction performance appraisal satisfaction is positively yet weakly correlated $(r=.333, \mathrm{p}<0.01)$ with employees' work performance. As well as there is positive but weak relationship between performance appraisal satisfaction and work performance $(\mathrm{r}=.384, \mathrm{p}<0.01)$. And also according to the above table it is noted that performance appraisal satisfaction is positively yet weakly correlated $(r=.243, \mathrm{p}<0.05)$ with employees' commitment.

Discussing the level of employees' motivation, work performance, employees' commitment and PA satisfaction in the sample, it was found that they have a high level of motivation, work performance, commitment and PA satisfaction with the mean value of more than 3.Accordingly it was found that employees' motivation, work performance, employees' commitment and PA satisfaction was good at Bank of Ceylon Head Office.

\section{Conclusion}

The purpose of conduct this research is to identify the relationship between performance appraisal satisfaction and the employees' 
outcomes in the form of employees' motivation, work performance and commitment. Researcher selected BOC Head Office to conduct this research. The questionnaire was developed for gather information and selected 110 employees as sample of research which covered clerical, executive officers and managerial level employees. Therefore research was conducted base on that data. As well as according to the analysis there is significant relationship between performance appraisal satisfaction and the employees' outcomes in the form of employees' motivation, work performance and commitment and it is weak positive relationship. So performance appraisal satisfaction helps to obtain positive employee outcomes in the form of employees' motivation, work performance and commitment. Therefore in order to obtain such positive outcomes, organization should provide a performance appraisal platform where employees must create satisfaction with performance appraisal. 


\section{Reference}

Angle, H. L., Perry, J. L. (1981) An empirical assessment of organizational commitment and organizational effectiveness. Administrative Science Quarterly, Vol. 26, No. 1. Retrieved from http://www.indiana.edu/jlpweb/papers

Jabeen, M. (2011). Impact of performance appraisal on employees motivation. Vol 3, No.4, 2011

Jamil, N. (2012).impact of the performance evaluation system on employee behavior in the marketing and human resource departments of a foreign bank in karachi. . Retrieved from http://www.pafkiet.edu.pk

Kelaniya Journal of Human Resource Management, Vol 2, No.2 (July 2007),

Luomanpa, R. (2012). Employee motivation at tommy bartlett, inc.

Luthan F. (1998) Organization behavior. (10th ed.). McGrow hill international edition.

Literature survey: www.scribd.com/doc/ questionnaire on employee motivation

Salleh, M., Amin, A., Muda, S., \& Halim, M. A. S. A., (2013)

Fairness of performance appraisal and organizational commitment. Vol. 9, No. 2; 2013 Retrieved from http://dx.doi.org/10.5539/ass.v9n2p121 
Selvarajan, T. T., \& Cloninger, P. A. (2011). Can performance appraisals motivate employees to improve performance? A Mexican study. The International Journal of Human Resource Management

Sekaran, U. (2006). Research methods for business. (4 ${ }^{\text {th }}$ ed.). John Wiley \& Sons inc

Vignaswaran, R. (2005). The relationship between performance appraisal satisfaction and employee outcomes: A study conducted in peninsular Malaysia. Retrieved from http://dspace.fsktm.um.edu.my/bitstream/1812/729/1/MBA Research Project.pdf

Wang, G. L., Lee, Y., \& Chih Ho, C. (2012). The Effects of Job Satisfaction, Organizational Commitment and Turnover intention on Organizational Operating Performance: as Exemplified with Employees of Listed Property Insurance Companies in Taiwan. 